\title{
Cardiac Arrhythmias and Electrocardiogram Modifications in Non-Alcoholic Fatty Liver Disease. A Systematic Review
}

\author{
Abdulrahman Ismaiel ${ }^{1,2}$, Horaţiu A. Colosi ${ }^{1,3}$, Flaviu Rusu ${ }^{1,2}$, Dan L. Dumitrașcu ${ }^{1,2}$
}

1) Iuliu Hațieganu University of Medicine and Pharmacy, Cluj-Napoca

2) $2^{\text {nd }}$ Department of Internal Medicine, Cluj-Napoca

3) Department of Medical Informatics and Biostatistics, Cluj-Napoca, Romania

\begin{abstract}
Background \& Aims: Recent studies have evaluated the relationship associating non-alcoholic fatty liver disease (NAFLD) with several electrocardiogram (ECG) findings, but the results have been inconsistent. The aim of this systematic review is to assess the association between NAFLD with ECG modifications.

Methods: We conducted a systematic search on PubMed with predefined keywords identifying observational studies published till 22 February 2019 with NAFLD diagnosed either by biopsy, imaging, surrogate markers or ICD code and ECG findings by either a standard ECG, 24-hour Holter ECG or ICD code. Quality assessment was performed using the quality assessment tools from the National Heart, Lung, and Blood Institute.

Results: A total of 20 observational studies (1 case-control, 4 cohort, 15 cross-sectional studies, 401,745 individuals) were included. Twelve studies evaluated cardiac arrhythmias in NAFLD subjects, out of which 10 evaluated atrial fibrillation (AF). Although results were inconsistent, most studies rated as "good" demonstrated that hepatic steatosis was independently associated with an increased risk for prevalent AF in NAFLD patients. Diabetic patients with NAFLD were associated with an increased risk of ventricular arrhythmias in only one study rated as "good". Two studies rated as "good" demonstrated that hepatic steatosis was associated with a prolonged QTc interval. Four studies supported the association between cardiac conduction abnormalities and NAFLD, out of which two were rated as "good". Two studies assessed ECG modifications of ischemic heart disease (IHD), but only one having a "good" rating confirmed this independent association.

Conclusions: Studies of high quality and with low risk of bias demonstrated that NAFLD is independently associated with AF, a prolonged QTc interval, bundle branch and atrioventricular blocks. Diabetic patients with NAFLD present an increased risk for developing ventricular arrhythmias.
\end{abstract}

Key words: non-alcoholic fatty liver disease - NAFLD - electrocardiogram - cardiac arrhythmias - atrial fibrillation - systematic review.

Abbreviations: AF: atrial fibrillation; AV: atrioventricular; CLD: chronic liver disease; CT: computed tomography; CV: cardiovascular; CVD: cardiovascular disease; DM: diabetes mellitus; ECG: electrocardiogram; FLI: fatty liver index; GGT: $\gamma$-glutamyl transpeptidase; ICD: International Classification of Diseases; IHD: ischemic heart disease; LVH: left ventricular hypertrophy; MRI: magnetic resonance imaging; NAFL: nonalcoholic fatty liver; NAFLD: non-alcoholic fatty liver disease; NASH: non-alcoholic steatohepatitis; NHLBI: National Heart, Lung, and Blood Institute; QTc interval: heart rate corrected QT interval; PRISMA: preferred reporting items for systematic reviews and meta-analyses; RBBB: right bundle branch block; SCD: sudden cardiac death; TE: transient elastography.

\section{INTRODUCTION}

Non-alcoholic fatty liver disease (NAFLD) was first described in the early 1980 s as "a poorly understood and hitherto unnamed liver disease" [1]. Knowledge has evolved rapidly over the past decades, NAFLD becoming the most common cause of chronic liver disease (CLD) in Western countries with an estimated prevalence of $10 \%-40 \%$ in adults worldwide [2]. It has been found to be associated with multiple cardiovascular (CV) risk factors including insulin resistance and other metabolic disorders increasing in prevalence, such as type 2 diabetes mellitus (DM) and obesity [3].

Over the last decade, NAFLD has been found to be associated with an increased liver-related morbidity and 
mortality as well as exerting an important role in several extrahepatic manifestations. Currently, NAFLD is considered a multisystem disease affecting a variety of extrahepatic organ systems, including the cardiovascular system $[4,5]$. The main leading mortality cause in NAFLD patients is ischemic heart disease (IHD) [4].

Electrocardiogram (ECG), a simple and widely used method to assess the cardiac electric activity, identifies and characterizes the existing or suspected cardiovascular disease (CVD), and predicts future clinical events that might be associated with cardiac function, also known as risk stratification. Despite the current advances in several imaging methods which detect structural alterations of the heart, ECG remains a unique method to evaluate vital information related to cardiac electrical activity, with the potential of diagnosing life-threatening conditions including tachyarrhythmias, bradyarrhythmias and ischemia.

Convincing evidence exists associating NAFLD with several CV complications evaluated by an ECG, such as cardiac arrhythmias (with atrial and ventricular origin), prolonged QT interval and cardiac conduction alterations [atrioventricular (AV) - and bundle branch blocks] [6].

Non-alcoholic fatty liver disease is an independent risk factor for atrial fibrillation (AF), the most common cardiac arrhythmia. Atrial fibrillation has an increasing prevalence with age. It is associated with a significant morbidity and mortality, and is one the most common causes of strokes [7]. Several pathogenic mechanisms have been suggested to link NAFLD with AF such as low adiponectin levels, insulin resistance and renin angiotensin aldosterone system, as well as promoting inflammation, oxidative stress and fibrosis through common disease pathways.

Moreover, ventricular arrhythmias have been established to be risk factors for sudden cardiac death (SCD). This association might be partially elucidated by the prolongation of the heart rate-corrected QT (QTc) interval that is also a known cause of SCD [8]. Furthermore, several cardiac conduction abnormalities have been found to be associated with NAFLD such as right bundle branch block, AV blocks as well as atrial conduction disturbances.

Cardiac arrhythmias including AF and ventricular tachycardia, in addition to bundle branch blocks, findings that were found to be associated with NAFLD, are predictive of future adverse CV events and usually herald the existence of an underlying CVD [9]. Therefore, the early detection of these ECG findings is vital for the prevention of further complications.

This systematic review was conducted with the aim of assessing the current literature regarding the risk of cardiac arrhythmias and ECG modifications in NAFLD patients.

\section{METHODS}

We conducted this systematic review as per the Preferred Reporting Items for Systematic Reviews and Meta-Analyses (PRISMA) guidelines.

\section{Data Sources and Search Strategy}

We performed a computerized search of PubMed database looking for all observational studies assessing the association between NAFLD and any ECG findings including cardiac arrhythmias of both atrial and ventricular origin, prolongation of QTc interval, cardiac conduction abnormalities and IHD findings on ECG. The search was conducted using the following search string keywords (non-alcoholic fatty liver disease OR NAFLD OR non-alcoholic steatohepatitis OR non-alcoholic steatosis OR fatty liver disease) AND (atrial fibrillation OR cardiac arrhythmia OR ventricular arrhythmia OR ECG OR electrocardiogram OR cardiac conduction OR QT interval). The literature search was carried out from inception up to 22 February 2019 with no duration, language or country restrictions. The titles and abstracts were reviewed for appropriateness. Full text review of the selected articles fulfilling the inclusion and exclusion criteria was performed. Articles were assessed and data was extracted from eligible studies independently by two authors (A.I. and F.R.). Extracted data discrepancies were resolved by mutual consensus. The final data was collated and presented in the review text.

\section{Eligibility Criteria}

Original articles had to meet the following inclusion criteria in order to be included in the systematic review: (1) observational cohort population-based or hospitalbased, case-control studies or studies that are not yet fully published but were presented as abstract, examining the association between NAFLD and any ECG findings or cardiac arrhythmias including atrial or ventricular arrhythmias; (2) NAFLD diagnosis confirmed by detection of hepatic steatosis using one of the following methods: biopsy or imaging techniques - ultrasonography, computed tomography (CT), magnetic resonance imaging (MRI), or surrogate markers of NAFLD, such as the fatty liver index (FLI), which includes in its equation anthropometric variables, serum triglyceride, glucose, $\gamma$-glutamyl transpeptidase (GGT) concentrations, in the absence of other secondary causes of hepatic steatosis, significant alcohol consumption based on each study definition and other causes of CLD; (3) diagnosis of cardiac arrhythmias performed on the basis of either standard ECG, 24 hour Holter monitoring, echocardiography or International Classification of Diseases (ICD) codes; (4) adult individuals (aged $\geq 18$ years) with no restrictions in terms of gender, race or ethnicity.

Exclusion criteria were as follows: (1) studies published in languages other than English language; (2) case reports, reviews, practice guidelines, commentaries and editorials; (3) studies that included also subjects with significant alcohol consumption or other known causes of CLD; (4) studies including patients with confirmed cirrhosis of any etiology or end-stage liver disease awaiting liver transplantation.

\section{Quality Assessment}

Quality assessment was performed using the quality assessment tools from the National Heart, Lung, and Blood Institute (NHLBI) for observational cohort, cross-sectional and case-control studies, respectively. Two authors (A.I. and H.C.) applied these tools independently. Each item on the evaluation assessment tool was answered using one of the following: "yes", "no", "not applicable", "cannot determine", or "not reported". Upon completion of the evaluation, the studies were rated as one of the following: "good", "fair", or "poor". Studies that were 
rated as poor were accompanied with an explanation of our rating. Any disagreement between the two authors was resolved through a discussion and by consulting the third researcher (D.D.). Eligibility of studies in this systematic review was not affected by the results of the methodological quality assessment.

\section{RESULTS}

The initial search yielded 149 articles in addition to 2 other articles that were added from other sources (Fig. 1). No duplicates were discovered. All the articles were assessed by their title and abstract regarding fulfillment of the inclusion and exclusion criteria. One hundred and fifty-one articles were screened: (1) 37 reviews (literature reviews $n=33$, meta-analysis $\mathrm{n}=2$, systematic reviews and meta-analysis $\mathrm{n}=2$ ), (2) 17 studies performed on animals, (3) 20 studies in languages other than English language (German $n=5$, Russian $n=5$, French $n=2$, Ukrainian $\mathrm{n}=2$, Japanese $\mathrm{n}=2$, Korean $\mathrm{n}=1$, Chinese $\mathrm{n}=1$, Italian $n=1$, Hebrew $n=1$ ), (4) 7 case reports or case series, (5) 50 other irrelevant studies to this review topic, (6) 22 article abstracts that met the primary criteria. We excluded 129 studies after the first screening. The remaining 22 articles underwent a thorough reading and evaluation of the full text in order to confirm fulfillment of our inclusion and exclusion criteria. One article was excluded due to the presence of alcoholic hepatic steatosis and another one was excluded as the full article was not found. We finally analysed 20 papers [10-29].

The main characteristics of the studies included in this review are summarized in Tables I-IV. This systematic review included a total number of 401,745 individuals (236,397 individuals in cohort studies, 164,588 individuals in cross-sectional studies and 700 individuals in a case-control study). The gender distribution was higher for females (approximately 63\%). NAFLD was present in about $16 \%$ of the total study sample.
Fifteen studies had a cross-sectional study design, whereas 4 had a longitudinal cohort design and 1 had a case-control design. Ten studies were undertaken in Europe (Italy $n=5$, Finland $n=2$, Turkey $n=2$, Germany $n=1), 5$ studies in Asia (Korea $\mathrm{n}=2$, China $\mathrm{n}=1$, Taiwan $\mathrm{n}=1$, India $\mathrm{n}=1$ ), 4 in the USA $(n=4)$, and 1 in the Middle East (Egypt $n=1)$.

\section{Definition of NAFLD}

Hepatic steatosis in NAFLD can be diagnosed by either imaging or histology in the absence of other secondary causes of hepatic fat accumulation, such as significant alcohol consumption, use of steatogenic medication or hereditary disorders [30]. NAFLD is composed of a wide spectrum of progressive liver disease ranging from non-alcoholic fatty liver (NAFL), which might cause progressive non-alcoholic steatohepatitis (NASH) and fibrosis, which may ultimately lead to hepatocellular carcinoma. Several non-invasive radiological imaging methods such as ultrasonography, CT scan and MRI, as well as transient elastography (TE) with controlled attenuated parameter (CAP) have been used to diagnose NAFLD. Nevertheless, the current gold standard for diagnosing NAFLD remains liver biopsy. Several scores based on serological and biochemical tests have been developed lately in order to act as surrogate markers for assessing the severity of liver fibrosis without the need of histological examination or imaging methods [30]. The diagnosis of NAFLD using abdominal ultrasonography is usually performed by assessing the echogenicity of the liver in comparison to that of the right kidney and the diaphragm (31). In our review, most studies used ultrasonography for diagnosing NAFLD $(n=13)$ [11, 13, 18-27, 29], while others used both ultrasonography and elastography $(n=2)[10,16]$, CT $(n=2)[15,28]$, either CT or ultrasonography $(n=1)[14]$, either ICD-9 code or biopsy $(n=1)$ [12] and 1 used FLI [17].
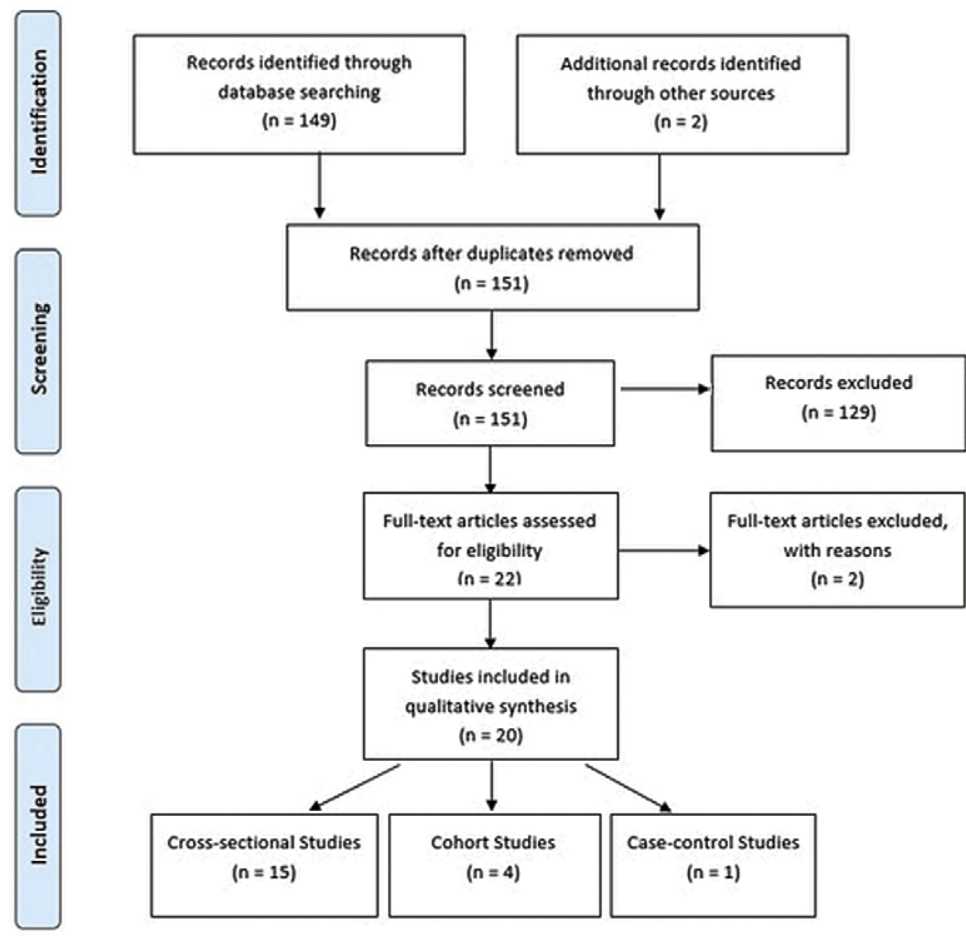

Fig. 1. The PRISMA flow diagram for the search and selection processes of this systematic review. 


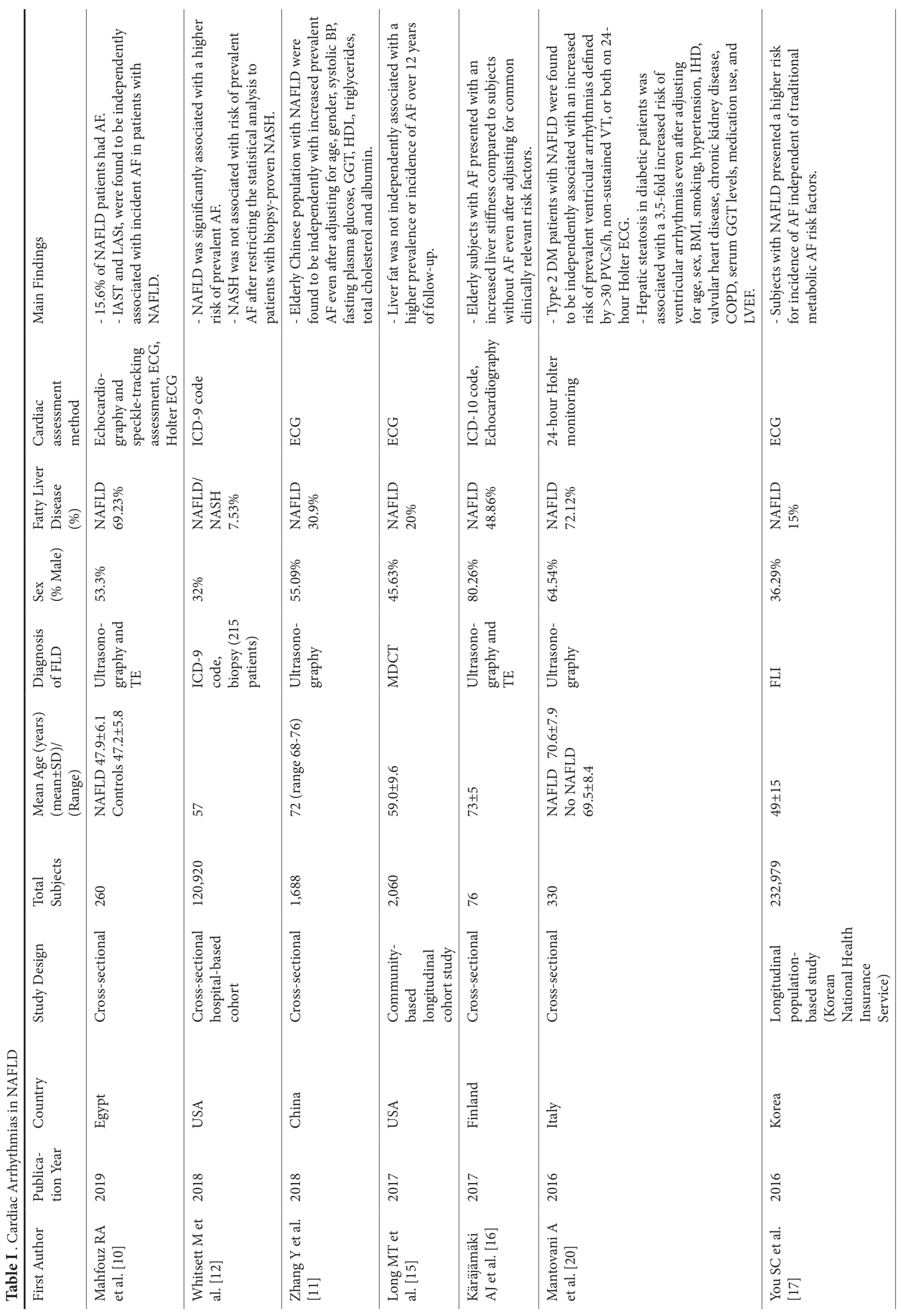




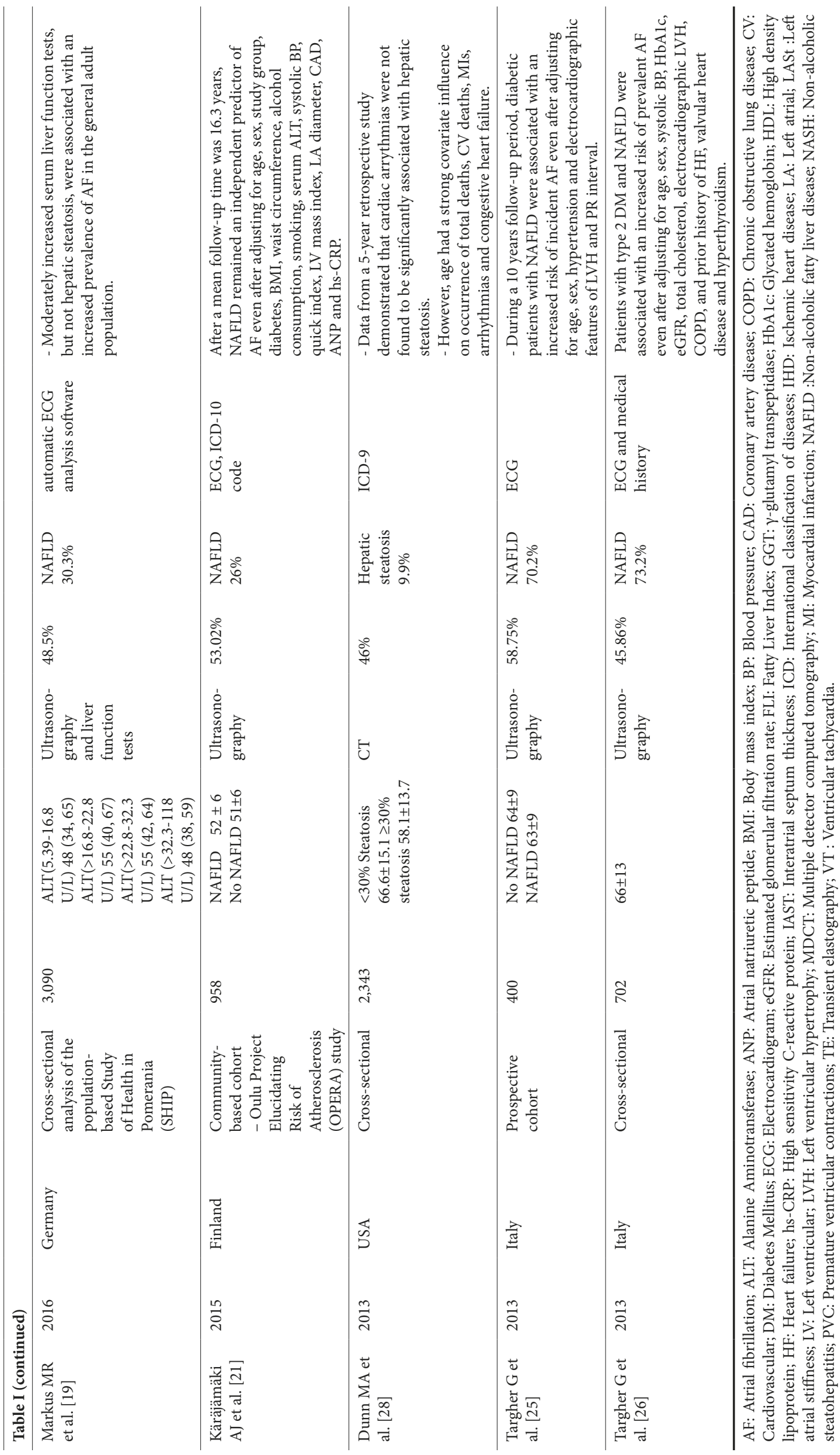




\section{Cardiac Arrhythmias}

A total of 12 studies assessed the association of NAFLD and cardiac arrhythmias (Table I). Atrial fibrillation was studied in 10 studies [10-12, 15-17, 19, 21, 25, 26], ventricular arrhythmias in 1 study [20] and 1 study did not mention which type of arrhythmia was present [28]. The diagnosis of cardiac arrhythmias was mainly based on standard ECG $(n=8)[10,11$, $15,17,19,21,25,26], 24$-hour Holter ECG ( $n=1)$ [20], ICD-9 $(\mathrm{n}=2)[12,28]$ and ICD-10 code $(\mathrm{n}=1)[16]$.

Three cross-sectional and 3 longitudinal cohort studies confirmed that NAFLD was significantly associated with AF, independent of common confounding factors [17, 17, 25].

The relationship between NAFLD and ventricular arrhythmias was evaluated only in one cross-sectional study conducted by Mantovani A et al. [20] on 330 type 2 diabetic patients, from who approximately $72 \%$ presented with NAFLD. The study concluded that type 2 diabetic patients with NAFLD independently associated a 3.5-fold increased risk of prevalent ventricular arrhythmias (defined by $>30$ premature ventricular contractions per hour, non-sustained ventricular tachycardia, or both on 24-hour Holter ECG) after adjusting for several possible confounding factors.

\section{Prolonged QTc interval}

Two cross-sectional studies assessed the association between NAFLD and prolongation of QTc interval (Table II) $[22,24]$.

\section{Cardiac Conduction Abnormalities}

A total of 3 cross-sectional studies and 1 case-control study evaluated the relationship between NAFLD and cardiac conduction abnormalities (Table III) $[13,14,18,27]$.

\section{ECG findings of Ischemic Heart Disease}

Two cross-sectional studies evaluated the association between NAFLD and ECG findings of IHD (Table IV) [23, 29].

\section{Quality Assessment}

NHLBI quality assessment tools were used to evaluate the methodological quality of eligible studies that were included in this systematic review (Supplementary Tables I-IV). The outcomes of this assessment were used as a measure to evaluate the internal validity and risk of bias for each study in a similar manner. The rating of the overall quality was reported as "good", "fair", or "poor". Fourteen studies had an overall rating of "good" [13-17, 19-26, 28], 4 studies were rated "fair" [10$12,27,29]$, and 1 was rated "poor" [18]. In general, all studies had a clearly stated research question or objective. Only one study mentioned that hepatic steatosis in NAFLD patients was assessed more than once over the study period [16]. All but 3 studies $[12,18,27]$ were adjusted for key potential confounding variables. Moreover, a few items of the quality assessment tools were not reported in some of the included studies.

\section{DISCUSSION}

To the best of our current knowledge, this is the first systematic review evaluating ECG abnormalities (including $\mathrm{AF}$ and ventricular arrhythmias, conduction abnormalities, prolonged QTc interval and IHD features) associated with NAFLD. Our systematic review included 20 studies (15 crosssectional studies, 4 cohort studies, 1 case-control study) with an approximate 400,000 individuals and found a strong evidence associating NAFLD with AF, prolonged QTc interval and

Table II. Prolongation of QTc Interval in NAFLD

\begin{tabular}{|c|c|c|c|c|c|c|c|c|c|c|}
\hline $\begin{array}{l}\text { First } \\
\text { Author }\end{array}$ & $\begin{array}{l}\text { Publica- } \\
\text { tion } \\
\text { Year }\end{array}$ & Country & $\begin{array}{l}\text { Study } \\
\text { Design }\end{array}$ & $\begin{array}{l}\text { Total } \\
\text { Subjects }\end{array}$ & $\begin{array}{l}\text { Mean Age } \\
\text { (years) } \\
\text { (mean } \pm \text { SD)/ } \\
\text { (Range) }\end{array}$ & $\begin{array}{l}\text { Diagnosis } \\
\text { of FLD }\end{array}$ & $\begin{array}{l}\text { Sex }(\% \\
\text { Male })\end{array}$ & $\begin{array}{l}\text { Fatty } \\
\text { Liver } \\
\text { Disease } \\
(\%)\end{array}$ & $\begin{array}{l}\text { Cardiac } \\
\text { assessment } \\
\text { method }\end{array}$ & Main Findings \\
\hline $\begin{array}{l}\text { Hung CS } \\
\text { et al. [22] }\end{array}$ & 2015 & Taiwan & $\begin{array}{l}\text { Cross- } \\
\text { sectional } \\
\text { analysis of a } \\
\text { community- } \\
\text { based study }\end{array}$ & 31,116 & $\begin{array}{l}\text { Total } \\
50.1 \pm 12.1\end{array}$ & $\begin{array}{l}\text { Ultraso- } \\
\text { nography }\end{array}$ & $50.93 \%$ & $\begin{array}{l}\text { NAFLD } \\
41.42 \%\end{array}$ & ECG & $\begin{array}{l}\text { - NAFLD severity was } \\
\text { associated with an } \\
\text { increased risk for QTc } \\
\text { prolongation in the general } \\
\text { population with and } \\
\text { without diabetes even after } \\
\text { adjusting for common } \\
\text { causes associated with QTc } \\
\text { interval. }\end{array}$ \\
\hline $\begin{array}{l}\text { Targher G } \\
\text { et al. [24] }\end{array}$ & 2014 & Italy & $\begin{array}{l}\text { Cross- } \\
\text { sectional }\end{array}$ & 400 & $\begin{array}{l}\text { QTc interval } \\
<416 \mathrm{~ms} \\
62 \pm 10 \text { QTc } \\
\text { interval } \\
>416 \mathrm{~ms} \\
64 \pm 9\end{array}$ & $\begin{array}{l}\text { Ultraso- } \\
\text { nography }\end{array}$ & $58.75 \%$ & $\begin{array}{l}\text { NAFLD } \\
70 \%\end{array}$ & ECG & $\begin{array}{l}\text { - Mean QTc interval } \\
\text { increased steadily } \\
\text { with the presence and } \\
\text { ultrasonographic severity } \\
\text { of NAFLD in type } 2 \text { DM } \\
\text { patients. } \\
\text { - NAFLD was associated } \\
\text { with increased } \\
\text { QTc interval even } \\
\text { after adjusting for } \\
\text { age, sex, smoking, } \\
\text { alcohol consumption, } \\
\text { BMI, hypertension, } \\
\text { electrocardiographic LVH, } \\
\text { diabetes-related variables } \\
\text { and comorbid conditions. }\end{array}$ \\
\hline
\end{tabular}


Table III. Conduction Abnormalities in NAFLD

\begin{tabular}{|c|c|c|c|c|c|c|c|c|c|c|}
\hline $\begin{array}{l}\text { First } \\
\text { Author }\end{array}$ & $\begin{array}{l}\text { Publica- } \\
\text { tion Year }\end{array}$ & Country & $\begin{array}{l}\text { Study } \\
\text { Design }\end{array}$ & $\begin{array}{l}\text { Total } \\
\text { Subjects }\end{array}$ & $\begin{array}{l}\text { Mean Age } \\
\text { (years) } \\
(\text { mean } \pm S D) / \\
\text { (Range) }\end{array}$ & $\begin{array}{l}\text { Diagnosis } \\
\text { of FLD }\end{array}$ & $\begin{array}{l}\text { Sex }(\% \\
\text { Male) }\end{array}$ & $\begin{array}{l}\text { Fatty } \\
\text { Liver } \\
\text { Disease } \\
(\%)\end{array}$ & $\begin{array}{l}\text { Cardiac } \\
\text { assessment } \\
\text { method }\end{array}$ & Main Findings \\
\hline $\begin{array}{l}\text { Mantovani } \\
\text { A et al. } \\
\text { [13] }\end{array}$ & 2017 & Italy & $\begin{array}{l}\text { Cross- } \\
\text { sectional } \\
\text { analysis of a } \\
\text { retrospective } \\
\text { hospital- } \\
\text { based } \\
\text { cohort }\end{array}$ & 751 & $\begin{array}{l}\text { Without } \\
\text { heart block } \\
64.0 \pm 13 \\
\text { With heart } \\
\text { block } \\
70.0 \pm 11\end{array}$ & $\begin{array}{l}\text { Ultraso- } \\
\text { nography }\end{array}$ & $53.92 \%$ & $\begin{array}{l}\text { NAFLD } \\
69.8 \%\end{array}$ & ECG & $\begin{array}{l}\text { - The presence of } \\
\text { hepatic steatosis and } \\
\text { its severity grading } \\
\text { were independently } \\
\text { associated with a } \\
\text { higher risk of prevalent } \\
\text { cardiac conduction } \\
\text { defects defined by at } \\
\text { least one heart block } \\
\text { among AV blocks or } \\
\text { bundle branch blocks } \\
\text { even after adjusting for } \\
\text { potentially confounding } \\
\text { factors such as age, } \\
\text { sex, hypertension, } \\
\text { prior IHD, HbAlc, } \\
\text { microvascular } \\
\text { complication status and } \\
\text { use of medications. }\end{array}$ \\
\hline $\begin{array}{l}\text { Mangi MA } \\
\text { et al. [14] }\end{array}$ & 2017 & USA & $\begin{array}{l}\text { Case-control } \\
\text { retrospective } \\
\text { study }\end{array}$ & 700 & $57.9 \pm 15.3$ & $\begin{array}{l}\text { Ultrasono- } \\
\text { graphy or } \\
\text { CT }\end{array}$ & $41.8 \%$ & $\begin{array}{l}\text { NAFLD } \\
58.28 \%\end{array}$ & ECG & $\begin{array}{l}\text { - Hepatic steatosis } \\
\text { was independently } \\
\text { associated with a } \\
\text { higher prevalence risk } \\
\text { of conduction defects } \\
\text { defined by at least one } \\
\text { heart block among AV } \\
\text { node blocks or bundle } \\
\text { branch blocks. }\end{array}$ \\
\hline $\begin{array}{l}\text { Ozveren O } \\
\text { et al. [18] }\end{array}$ & 2016 & Turkey & $\begin{array}{l}\text { Cross- } \\
\text { sectional }\end{array}$ & 81 & $\begin{array}{l}\text { NAFLD } \\
42 \pm 9 \\
\text { Controls } \\
41 \pm 6\end{array}$ & $\begin{array}{l}\text { Ultraso- } \\
\text { nography }\end{array}$ & $50.61 \%$ & $\begin{array}{l}\text { NAFLD } \\
72.83 \%\end{array}$ & $\begin{array}{l}\text { Echocar- } \\
\text { diography, } \\
\text { ECG }\end{array}$ & $\begin{array}{l}\text { - Atrial conduction was } \\
\text { impaired in patients } \\
\text { with NAFLD assessed } \\
\text { by electromechanical } \\
\text { delay derived from } \\
\text { Doppler tissue } \\
\text { echocardiography } \\
\text { examination and } \\
\text { P-wave dispersion } \\
\text { calculated from the 12- } \\
\text { lead electrocardiogram. }\end{array}$ \\
\hline $\begin{array}{l}\text { Ozveren O } \\
\text { et al. [18] }\end{array}$ & 2016 & Turkey & $\begin{array}{l}\text { Cross- } \\
\text { sectional }\end{array}$ & 81 & $\begin{array}{l}\text { NAFLD } \\
42 \pm 9 \\
\text { Controls } \\
41 \pm 6\end{array}$ & $\begin{array}{l}\text { Ultraso- } \\
\text { nography }\end{array}$ & $50.61 \%$ & $\begin{array}{l}\text { NAFLD } \\
72.83 \%\end{array}$ & $\begin{array}{l}\text { Echocar- } \\
\text { diography, } \\
\text { ECG }\end{array}$ & $\begin{array}{l}\text { - Atrial conduction was } \\
\text { impaired in patients } \\
\text { with NAFLD assessed } \\
\text { by electromechanical } \\
\text { delay derived from } \\
\text { Doppler tissue } \\
\text { echocardiography } \\
\text { examination and } \\
\text { P-wave dispersion } \\
\text { calculated from the 12- } \\
\text { lead electrocardiogram. }\end{array}$ \\
\hline $\begin{array}{l}\text { İşcen S } \\
{[27]}\end{array}$ & 2013 & Turkey & $\begin{array}{l}\text { Cross- } \\
\text { sectional }\end{array}$ & 2,200 & $\begin{array}{l}\text { With RBBB } \\
32.1 \pm 2.2 \\
\text { Without } \\
\text { RBBB } \\
32.4 \pm 2.1\end{array}$ & $\begin{array}{l}\text { Ultraso- } \\
\text { nography }\end{array}$ & $100 \%$ & $\begin{array}{l}\text { NAFLD } \\
5 \%\end{array}$ & ECG & $\begin{array}{l}\text { - RBBB is associated } \\
\text { with an increased } \\
\text { prevalence of NAFLD } \\
\text { in young healthy } \\
\text { individuals. }\end{array}$ \\
\hline
\end{tabular}

AF - Atrial fibrillation; AV - Atrioventricular; CT - Computed tomography; ECG - Electrocardiogram; HbAlc - Glycated hemoglobin; IHD - Ischemic heart disease; NAFLD - Non-alcoholic fatty liver disease; RBBB - Right bundle branch block.

cardiac conduction abnormalities. Most of these associations were found to be independently associated with NAFLD regardless of traditional risk factors across a wide range of patient population.
Our review evaluated the association between NAFLD and ECG changes, as well as identified several issues that require further discussion. Firstly, we observed that the prevalence of NAFLD was approximately $16 \%$, in agreement with the 
Table IV. Ischemic Heart Disease findings on ECG in NAFLD

\begin{tabular}{|c|c|c|c|c|c|c|c|c|c|c|}
\hline $\begin{array}{l}\text { First } \\
\text { Author }\end{array}$ & $\begin{array}{l}\text { Publica- } \\
\text { tion } \\
\text { Year }\end{array}$ & Country & $\begin{array}{l}\text { Study } \\
\text { Design }\end{array}$ & $\begin{array}{l}\text { Total } \\
\text { Subjects }\end{array}$ & $\begin{array}{l}\text { Mean Age } \\
\text { (years) } \\
\text { (mean } \pm \text { SD)/ } \\
\text { (Range) }\end{array}$ & $\begin{array}{l}\text { Diagnosis } \\
\text { of FLD }\end{array}$ & $\begin{array}{l}\text { Sex }(\% \\
\text { Male) }\end{array}$ & $\begin{array}{l}\text { Fatty } \\
\text { Liver } \\
\text { Disease } \\
(\%)\end{array}$ & $\begin{array}{l}\text { Cardiac } \\
\text { assessment } \\
\text { method }\end{array}$ & Main Findings \\
\hline $\begin{array}{l}\text { Vendhan } \\
\text { R et al. } \\
\text { [23] }\end{array}$ & 2014 & India & $\begin{array}{l}\text { Cross- } \\
\text { sectional }\end{array}$ & 541 & $\begin{array}{l}\text { Non- } \\
\text { NAFLD } \\
42 \pm 13 \\
\text { Non-obese } \\
\text { NAFLD } \\
46 \pm 14 \\
\text { Overweight } \\
\text { NAFLD } \\
46 \pm 11\end{array}$ & $\begin{array}{l}\text { Ultraso- } \\
\text { nography }\end{array}$ & $47.87 \%$ & $\begin{array}{l}\text { NAFLD } \\
32 \%\end{array}$ & ECG & $\begin{array}{l}\text { - Multiple logistic regression } \\
\text { analysis showed a significant } \\
\text { association between nonobese } \\
\text { NAFLD and CAD defined by } \\
\text { ECG changes including ST- } \\
\text { segment depression, Q-wave } \\
\text { changes, or T-wave changes } \\
\text { associated with IHD even after } \\
\text { adjusting for age, diabetes, } \\
\text { hypercholesterolemia, HOMA- } \\
\text { IR, and hypertension. }\end{array}$ \\
\hline $\begin{array}{l}\text { Lee } S \text { et } \\
\text { al. [29] }\end{array}$ & 2006 & Korea & $\begin{array}{l}\text { Cross- } \\
\text { sectional }\end{array}$ & 150 & $\begin{array}{l}\text { NAFLD } \\
49.19 \pm 12.9 \\
\text { Controls } \\
47.89 \pm 10.5\end{array}$ & $\begin{array}{l}\text { Ultraso- } \\
\text { nography }\end{array}$ & $33.33 \%$ & $\begin{array}{l}\text { NAFLD } \\
33.33 \%\end{array}$ & ECG & $\begin{array}{l}\text { - NAFLD was associated with } \\
\text { hypertriglyceridemia, impaired } \\
\text { fasting glucose, silent myocardial } \\
\text { ischemic pattern of ECG, obesity, } \\
\text { and abnormal liver tests in adults. } \\
\text { - Obesity was the only } \\
\text { independent factor associated } \\
\text { with NAFLD. }\end{array}$ \\
\hline
\end{tabular}

CAD: Coronary artery disease; ECG: Electrocardiogram; HOMA-IR: Homeostatic model assessment - insulin resistance; IHD: Ischemic heart disease; NAFLD: Non-alcoholic fatty liver disease.

study by Clark et al. [32], which estimated the prevalence of NAFLD ranging between $3 \%$ to $24 \%$. Moreover, a more recent meta-analysis by Younossi et al. [33] assessing the prevalence, incidence and outcomes of NAFLD involving 86 studies with a study sample size of $8,515,431$ from 22 countries estimated that the global prevalence of NAFLD was $25.24 \%$. They also mentioned that the highest prevalence was in the Middle East and South America and the lowest one in Africa. One study in our systematic review conducted in Egypt demonstrated a high prevalence of NAFLD, similar to the findings of Younossi et al. [33], but the highest prevalence in their study was actually found in Italy and Turkey. This might be explained by the fact that these studies were mainly either hospital-based studies or involving diabetic patients, who are known to have an increased risk of developing NAFLD and metabolic syndrome (MetS).

Secondly, we observed a wide variability in the methods used to diagnose NAFLD. A positive diagnosis of NAFLD can be confirmed by imaging methods or histology [30]. The solo use of liver enzymes in diagnosing NAFLD is debatable, as they may be normal in up to $70 \%$ of patients [34]. At present, ultrasonography remains the most common investigational method to diagnose NAFLD, as demonstrated by most studies in our review. Although ultrasonography demonstrates a low sensitivity when hepatic steatosis is less than $20 \%$ on biopsy, it still remains the preferred initial first-line imaging method to evaluate liver fat [35]. A meta-analysis conducted by Hernaez et al. [36] concluded that liver ultrasonography was an accurate and reliable tool to detect moderate to severe hepatic steatosis, with sensitivity and specificity of $84.8 \%$ and $93.6 \%$, respectively. Compared to ultrasonography, CT scan use was limited to fewer studies. Transient elastography is one of the few efficient imaging methods of assessing and grading hepatic steatosis and fibrosis [37]. In our study, only in two articles TE was used. Other imaging modalities used to diagnose NAFLD are MRI and magnetic resonance spectroscopy, but they are relatively expensive and time consuming [37].

Thirdly, we found an increased risk of developing cardiac arrhythmias such as AF and ventricular arrhythmias in NAFLD patients. The recent meta-analysis by Mantovani et al. [38] involving 9 cross-sectional and longitudinal studies with a study sample of 364,919 subjects concluded that NAFLD was associated with an increased risk of AF in middle-aged and elderly subjects especially type 2 diabetics. Another meta-analysis assessing the relationship between NAFLD and AF conducted by Wijarnpreecha et al. [39] involving 5 studies out of which 2 were cross-sectional studies and 3 were cohort studies with 238,129 participants concluded that NAFLD patients were at a significantly increased risk for developing AF compared to subjects without NAFLD. In addition, other reviews confirmed the association between NAFLD and AF $[40,41]$. To date, only in the cross-sectional study conducted by Mantovani A et al. [20] an increased risk of ventricular arrhythmias in diabetic patients with NAFLD was reported. This relationship has not been evaluated yet in NAFLD patients without DM. The exact pathogenic causes associating NAFLD with cardiac arrhythmias remain unknown. Several factors have been suggested to be involved in this mechanistic complicated relationship involving structural, functional and biological alterations. Mantovani [42] conducted a recent literature review explaining several possible mechanisms involved in the increased risk of cardiac arrhythmias in NAFLD. He mentioned that dysglycemia, insulin resistance, atherogenic dyslipidemia, chronic inflammation, oxidative stress, hypercoagulable or procoagulant states and left ventricular dysfunction, pathological processes found in NAFLD could cause structural and electrical cardiac alterations, leading to an increased risk of atrial and ventricular arrhythmias in addition to a prolonged QTc interval. Two studies evaluated the presence of a prolonged QTc interval in NAFLD patients demonstrating 
that the presence of NAFLD as well as hepatic steatosis severity were independently associated with a prolonged QTc interval even after adjusting for common confounding factors, which can further lead to an increased risk of SCD [22, 24].

Fourthly, we noticed that NAFLD patients had an independent increased risk for developing cardiac conduction alterations such as AV blocks and bundle branch blocks. The exact mechanism behind this finding is not established. Possible attributable causes might be due to the structural and functional cardiac modifications present in patients with NAFLD such as left ventricular diastolic dysfunction, LVH, left atrial enlargement, heart failure, coronary atherosclerosis, IHD, aortic valvular sclerosis, mitral annular calcification as well as cardiac arrhythmias [43].

Fifthly, although NAFLD is well known to be associated with coronary artery disease as well as subclinical atherosclerotic disease, our systematic review identified the paucity of the presence of ECG modifications associating NAFLD with IHD. Further studies are required to confirm this association. Currently, only two cross-sectional studies assessed this relationship as described in the results section. Epicardial adipose tissue is a strong predictor of metabolic syndrome and obesity, which are known risk factors for CVD leading to several $\mathrm{CV}$ complications such as IHD, subclinical atherosclerosis, as well as diastolic dysfunction [44-47].

Quality assessment of the included studies demonstrated that most of them had good methodological quality and a low risk of bias and supported the association of NAFLD with AF, ventricular arrhythmias, prolonged QTc interval, cardiac conduction alterations and ECG findings of IHD.

Some important potential limitations in our systematic review should be mentioned. We analyzed only the studies published in PubMed. The observational design of the studies mentioned in this review does not establish a clear causal correlation between NAFLD and cardiac arrhythmias, cardiac conduction abnormalities, IHD findings on ECG or a prolonged QTc interval. Most studies diagnosed cardiac arrhythmias using a standard ECG and not through a 24-hour Holter ECG, so that in some subjects paroxysmal cardiac arrhythmias might have been missed. Ventricular arrhythmias have been evaluated only in one study involving NAFLD patients with type $2 \mathrm{DM}$ which does not make this finding generalizable on all NAFLD patients. Finally, most studies used ultrasonography and to a lesser extent CT, TE, FLI and ICD codes to assess hepatic steatosis; only one study used liver biopsy which is the current gold standard for diagnosing and staging of NAFLD [48].

Despite the previously mentioned limitations, our systematic review has also important strengths. We believe that the topic of our systematic review is practically and clinically relevant due to the rapid increase in the prevalence of NAFLD in addition to other cardiac arrhythmias such as AF worldwide. This systematic review provides the most updated evaluation about the relationship between NAFLD and ECG findings including cardiac arrhythmias of atrial and ventricular origin, cardiac conduction abnormalities, prolonged QTc interval as well as IHD.

Future research involving larger cohort studies of well characterized NAFLD patients is required to evaluate possible pathophysiological mechanisms underlying the relationship associating NAFLD and liver fibrosis severity with cardiac arrhythmias, prolonged QTc interval and conduction anomalies.

\section{CONCLUSION}

The present systematic review demonstrates a significant association of NAFLD with cardiac arrhythmias, prolongation of QTc interval, IHD findings on ECG and cardiac conduction alterations. It supports the role of NAFLD as an independent predictor of CVD. We emphasize the importance of performing a thorough ECG assessment in NAFLD patients.

\section{Conflicts of interests: None to declare.}

Authors' contribution: A.I. drafted the manuscript. H.C. conducted the search methodology. A.I. and F.R. data analysis. A.I. and H.C. quality assessment. D.D made substantial contributions to conception, literature survey, methodology and writing of the manuscript. All authors revised the final manuscript and approved the final version.

Supplementary material: To access the supplementary material visit the online version of the J Gastrointestin Liver Dis at http://dx.doi. org/10.15403/jgld-344

\section{REFERENCES}

1. Ludwig J, Viggiano TR, McGill DB, Oh BJ. Nonalcoholic steatohepatitis: Mayo Clinic experiences with a hitherto unnamed disease. Mayo Clin Proc 1980;55:434-438.

2. Brunt EM, Wong VW, Nobili V, et al. Nonalcoholic fatty liver disease. Nat Rev Dis Primers 2015;1:15080. doi:10.1038/nrdp.2015.80

3. Adams LA, Waters OR, Knuiman MW, Elliott RR, Olynyk JK. NAFLD as a risk factor for the development of diabetes and the metabolic syndrome: an eleven-year follow-up study. Am J Gastroenterol 2009;104:861-867.

4. Targher G, Day CP, Bonora E. Risk of cardiovascular disease in patients with nonalcoholic fatty liver disease. N Engl J Med 2010;363:1341-1350. doi:10.1056/NEJMra0912063

5. Byrne CD, Targher G. NAFLD: a multisystem disease. J Hepatol 2015;62(1 Suppl):S47-S64. doi:10.1016/j.jhep.2014.12.012

6. Mantovani A, Ballestri S, Lonardo A, Targher G. Cardiovascular Disease and Myocardial Abnormalities in Nonalcoholic Fatty Liver Disease. Dig Dis Sci 2016;61:1246-1267. doi:10.1007/s10620-016-4040-6

7. Lloyd-Jones DM, Wang TJ, Leip EP, et al. Lifetime risk for development of atrial fibrillation: the Framingham Heart Study. Circulation 2004;110:1042-1046. doi:10.1161/01.cir.0000140263.20897.42

8. O’Neal WT, Singleton MJ, Roberts JD, et al. Association Between QT-Interval Components and Sudden Cardiac Death. Circ Arrhythm Electrophysiol 2017;10:e005485. doi:10.1161/CIRCEP.117.005485

9. Chow GV, Marine JE, Fleg JL. Epidemiology of arrhythmias and conduction disorders in older adults. Clin Geriatr Med 2012;28:539553. doi:10.1016/j.cger.2012.07.003

10. Mahfouz RA, Gouda M, Galal I, Ghareb MS. Interatrial septal fat thickness and left atrial stiffness are mechanistic links between nonalcoholic fatty liver disease and incident atrial fibrillation. Echocardiography 2019;36:249-256. doi:10.1111/echo.14229 
11. Zhang Y, Li P, Miao M, et al. Nonalcoholic Fatty Liver Disease Is Associated with Increased Atrial Fibrillation Risk in an Elderly Chinese Population: A Cross-Sectional Study. Biomed Res Int 2018;2018:5628749. doi:10.1155/2018/5628749

12. Whitsett M, Wilcox J, Yang A, Zhao L, Rinella M, VanWagner LB. Atrial fibrillation is highly prevalent yet undertreated in patients with biopsy-proven nonalcoholic steatohepatitis. Liver Int 2019;39:933-940. doi:10.1111/liv.14018

13. Mantovani A, Rigolon R, Pichiri I, et al. Nonalcoholic fatty liver disease is associated with an increased risk of heart block in hospitalized patients with type 2 diabetes mellitus. PLoS One 2017;12:e0185459. doi:10.1371/ journal.pone.0185459

14. Mangi MA, Minhas AM, Rehman H, Pathan F, Liang H, Beidas S Association of Non-alcoholic Fatty Liver Disease with Conduction Defects on Electrocardiogram. Cureus 2017;9:e1107. doi:10.7759/cureus.1107

15. Long MT, Yin X, Larson MG, et al. Relations of Liver Fat With Prevalent and Incident Atrial Fibrillation in the Framingham Heart Study. J Am Heart Assoc 2017;6.e005227. doi:10.1161/JAHA.116.005227

16. Karajamaki AJ, Kettunen O, Lepojarvi S, et al. Presence of atria fibrillation is associated with liver stiffness in an elderly Finnish population. PLoS One 2017;12:e0173855. doi:10.1371/journal. pone. 0173855

17. You SC, Yang PS, Kim TH, et al. Non-alcoholic fatty liver disease is independently associated with new onset atrial fibrillation: a nationwide cohort study in Korea. J Am Coll Cardiol 2016;67(13 Supplement):854. doi:10.1016/s0735-1097(16)30855-5

18. Ozveren O, Izgi C, Eroglu E, et al. Doppler Tissue Evaluation of Atrial Conduction Properties in Patients With Non-alcoholic Fatty-liver Disease. Ultrason Imaging 2016;38:225-235. doi:10.1177/0161734615595015

19. Markus MR, Meffert PJ, Baumeister SE, et al. Association between hepatic steatosis and serum liver enzyme levels with atrial fibrillation in the general population: The Study of Health in Pomerania (SHIP). Atherosclerosis 2016;245:123-131. doi:10.1016/j. atherosclerosis.2015.12.023

20. Mantovani A, Rigamonti A, Bonapace S, et al. Nonalcoholic Fatty Liver Disease Is Associated With Ventricular Arrhythmias in Patients With Type 2 Diabetes Referred for Clinically Indicated 24-Hour Holter Monitoring. Diabetes Care 2016;39:1416-1423. doi:10.2337/dc16-0091

21. Karajamaki AJ, Patsi OP, Savolainen M, Kesaniemi YA, Huikuri H, Ukkola O. Non-Alcoholic Fatty Liver Disease as a Predictor of Atria Fibrillation in Middle-Aged Population (OPERA Study). PLoS One 2015;10:e0142937. doi:10.1371/journal.pone.0142937

22. Hung CS, Tseng PH, Tu CH, et al. Nonalcoholic Fatty Liver Disease Is Associated With QT Prolongation in the General Population. J Am Heart Assoc 2015;4:e001820. doi:10.1161/jaha.115.001820

23. Vendhan R, Amutha A, Anjana RM, Unnikrishnan R, Deepa M, Mohan $\mathrm{V}$. Comparison of characteristics between nonobese and overweight/obese subjects with nonalcoholic fatty liver disease in a South Indian population. Diabetes Technol Ther 2014;16:48-55. doi:10.1089/dia.2013.0165

24. Targher G, Valbusa F, Bonapace S, et al. Association of nonalcoholic fatty liver disease with QTc interval in patients with type 2 diabetes. Nutr Metab Cardiovasc Dis 2014;24:663-669. doi:10.1016/j. numecd.2014.01.005

25. Targher G, Valbusa F, Bonapace S, et al. Non-alcoholic fatty liver disease is associated with an increased incidence of atrial fibrillation in patients with type 2 diabetes. PLoS One 2013;8:e57183. doi:10.1371/journal. pone. 0057183
26. Targher G, Mantovani A, Pichiri I, et al. Non-alcoholic fatty liver disease is associated with an increased prevalence of atrial fibrillation in hospitalized patients with type 2 diabetes. Clin Sci (Lond) 2013;125:301309. doi:10.1042/cs20130036

27. Iscen $\mathrm{S}$. RBBB is associated with an increased risk of NAFLD in young healthy individuals. Int J Cardiol 2013;168:4056-4057. doi:10.1016/j. ijcard.2013.07.035

28. Dunn MA, Behari J, Rogal SS, et al. Hepatic steatosis in diabetic patients does not predict adverse liver-related or cardiovascular outcomes. Liver Int 2013;33:1575-1582. doi:10.1111/liv.12285

29. Lee S, Jin Kim Y, Yong Jeon T, et al. Obesity is the only independent factor associated with ultrasound-diagnosed non-alcoholic fatty liver disease: a cross-sectional case-control study. Scand J Gastroenterol 2006;41:566-572. doi:10.1080/00365520500319591

30. Dumitrascu DL, Neuman MG. Non-alcoholic fatty liver disease: an update on diagnosis. Clujul Med 2018;91:147-150. doi:10.15386/ cjmed-993

31. Mishra P, Younossi ZM. Abdominal Ultrasound for Diagnosis of Nonalcoholic Fatty Liver Disease (NAFLD). Am J Gastroenterol 2007;102:2716-2717.

32. Clark JM. The epidemiology of nonalcoholic fatty liver disease in adults. J Clin Gastroenterol 2006;40 Suppl 1:S5-S10.

33. Younossi ZM, Koenig AB, Abdelatif D, Fazel Y, Henry L, Wymer M. Global epidemiology of nonalcoholic fatty liver disease-Meta-analytic assessment of prevalence, incidence, and outcomes. Hepatology 2016;64:73-84. doi:10.1002/hep.28431

34. Targher G. Non-alcoholic fatty liver disease, the metabolic syndrome and the risk of cardiovascular disease: the plot thickens. Diabet Med 2007;24:1-6. doi:10.1111/j.1464-5491.2007.02025.x

35. Dasarathy S, Dasarathy J, Khiyami A, Joseph R, Lopez R, McCullough AJ. Validity of real time ultrasound in the diagnosis of hepatic steatosis: a prospective study. J Hepatol 2009;51:1061-4067. doi:10.1016/j. jhep.2009.09.001

36. Hernaez R, Lazo M, Bonekamp S, et al. Diagnostic accuracy and reliability of ultrasonography for the detection of fatty liver: a metaanalysis. Hepatology 2011;54:1082-1090. doi:10 .1002/hep.24452

37. Sporea I, Popescu A, Dumitrascu D, et al. Nonalcoholic Fatty Liver Disease: Status Quo. J Gastrointestin Liver Dis 2018;27:439-448. doi:10.15403/jgld.2014.1121.274.quo

38. Mantovani A, Dauriz M, Sandri D, et al. Association between nonalcoholic fatty liver disease and risk of atrial fibrillation in adult individuals: an updated meta-analysis. Liver Int 2019;39:758-769. doi:10.1111/liv.14044

39. Wijarnpreecha K, Boonpheng B, Thongprayoon C, Jaruvongvanich V, Ungprasert $\mathrm{P}$. The association between non-alcoholic fatty liver disease and atrial fibrillation: A meta-analysis. Clin Res Hepatol Gastroenterol 2017;41:525-532. doi:10.1016/j.clinre.2017.08.001

40. Minhas AM, Usman MS, Khan MS, Fatima K, Mangi MA, Illovsky MA Link Between Non-Alcoholic Fatty Liver Disease and Atrial Fibrillation: A Systematic Review and Meta-Analysis. Cureus 2017;9:e1142. doi:10.7759/cureus.1142

41. Mantovani A, Dauriz M, Sandri D, et al. Association between nonalcoholic fatty liver disease and risk of atrial fibrillation in adult individuals: An updated meta-analysis. Liver Int 2019;39:758-769. doi:10.1111/liv.14044

42. Mantovani A. Nonalcoholic Fatty Liver Disease (NAFLD) and Risk of Cardiac Arrhythmias: A New Aspect of the Liver-heart Axis. J Clin Transl Hepatol 2017;5:134-141. doi:10.14218/JCTH.2017.00005 
43. Anstee QM, Mantovani A, Tilg H, Targher G. Risk of cardiomyopathy and cardiac arrhythmias in patients with nonalcoholic fatty liver disease. Nat Rev Gastroenterol Hepatol 2018;15:425-439. doi:10.1038/s41575018-0010-0

44. Rhee TM, Kim HL, Lim WH, et al. Association between epicardial adipose tissue thickness and parameters of target organ damage in patients undergoing coronary angiography. Hypertens Res 2019;42:549557. doi:10.1038/s41440-018-0180-8

45. Rabkin SW. The relationship between epicardial fat and indices of obesity and the metabolic syndrome: a systematic review and metaanalysis. Metab Syndr Relat Disord 2014;12:31-42. doi:10.1089/ met.2013.0107
46. Colak Y, Karabay CY, Tuncer I, et al. Relation of epicardial adipose tissue and carotid intima-media thickness in patients with nonalcoholic fatty liver disease. Eur J Gastroenterol Hepatol 2012;24:613-618. doi:10.1097/ MEG.0b013e3283513f19

47. Meng X, Wang W, Zhang K, et al. Epicardial adipose tissue volume is associated with non-alcoholic fatty liver disease and cardiovascular risk factors in the general population. Ther Clin Risk Manag 2018;14:14991506. doi:10.2147/TCRM.S168345

48. Chalasani N, Younossi Z, Lavine JE, et al. The diagnosis and management of nonalcoholic fatty liver disease: Practice guidance from the American Association for the Study of Liver Diseases 2018;67:328357. doi:10.1002/hep.29367 
Supplementary Table I. NHLBI Quality Assessment Tool for Observational Cohort and Cross-Sectional Studies

\begin{tabular}{|c|c|c|c|c|c|c|}
\hline Criteria & $\begin{array}{l}\text { Mahfouz RA } \\
\text { et al. [10] }\end{array}$ & $\begin{array}{l}\text { Whitsett M } \\
\text { et al. [12] }\end{array}$ & $\begin{array}{l}\text { Zhang Y et } \\
\text { al. [11] }\end{array}$ & $\begin{array}{l}\text { Long MT et } \\
\text { al. [15] }\end{array}$ & $\begin{array}{l}\text { Käräjämäki } \\
\text { AJ et al. [16] }\end{array}$ & $\begin{array}{l}\text { Mantovani A } \\
\text { et al. [20] }\end{array}$ \\
\hline 1. Was the research question or objective in this paper clearly stated? & Yes & Yes & Yes & Yes & Yes & Yes \\
\hline 2. Was the study population clearly specified and defined? & $\mathrm{CD}$ & Yes & Yes & Yes & Yes & Yes \\
\hline 3. Was the participation rate of eligible persons at least 50\%? & $\mathrm{CD}$ & Yes & Yes & Yes & No & Yes \\
\hline $\begin{array}{l}\text { 4. Were all the subjects selected or recruited from the same or similar populations } \\
\text { (including the same time period)? Were inclusion and exclusion criteria for being in the } \\
\text { study prespecified and applied uniformly to all participants? }\end{array}$ & $\mathrm{CD}$ & Yes & Yes & Yes & Yes & Yes \\
\hline $\begin{array}{l}\text { 5. Was a sample size justification, power description, or variance and effect estimates } \\
\text { provided? }\end{array}$ & No & Yes & No & Yes & Yes & Yes \\
\hline $\begin{array}{l}\text { 6. For the analyses in this paper, were the exposure(s) of interest measured prior to the } \\
\text { outcome }(s) \text { being measured? }\end{array}$ & No & No & No & Yes & No & No \\
\hline $\begin{array}{l}\text { 7. Was the time frame sufficient so that one could reasonably expect to see an association } \\
\text { between exposure and outcome if it existed? }\end{array}$ & No & No & No & Yes & No & No \\
\hline $\begin{array}{l}\text { 8. For exposures that can vary in amount or level, did the study examine different levels of } \\
\text { the exposure as related to the outcome (e.g., categories of exposure, or exposure measured } \\
\text { as continuous variable)? }\end{array}$ & Yes & No & No & No & Yes & No \\
\hline $\begin{array}{l}\text { 9. Were the exposure measures (independent variables) clearly defined, valid, reliable, and } \\
\text { implemented consistently across all study participants? }\end{array}$ & Yes & Yes & Yes & Yes & Yes & Yes \\
\hline 10. Was the exposure(s) assessed more than once over time? & No & No & No & No & Yes & No \\
\hline $\begin{array}{l}\text { 11. Were the outcome measures (dependent variables) clearly defined, valid, reliable, and } \\
\text { implemented consistently across all study participants? }\end{array}$ & Yes & Yes & No & Yes & Yes & Yes \\
\hline 12. Were the outcome assessors blinded to the exposure status of participants? & Yes & NR & Yes & NR & Yes & NR \\
\hline 13. Was loss to follow-up after baseline $20 \%$ or less? & NA & $\mathrm{NA}$ & NA & NR & NA & NA \\
\hline $\begin{array}{l}\text { 14. Were key potential confounding variables measured and adjusted statistically for their } \\
\text { impact on the relationship between exposure( }(s) \text { and outcome }(s) \text { ? }\end{array}$ & Yes & No & Yes & Yes & Yes & Yes \\
\hline Rating & Fair & Fair & Fair & Good & Good & Good \\
\hline
\end{tabular}

Available at: https://www.nhlbi.nih.gov/health-topics/study-quality-assessment-tools. CD, cannot determine; NA, not applicable; NR, not reported.

Five out of the seven studies rated as "good" $[16,17,21,25,26]$, that evaluated the relationship between NAFLD and atrial fibrillation demonstrated that NAFLD is independently associated with atrial fibrillation, while the other two studies disagreed with this association [15, 19]. The remaining three studies supporting this relationship were rated as "fair" [10-12]. Ventricular arrhythmias in NAFLD patients was evaluated in one study that was rated as "good" and supported this association [20]. On the other hand, one study rated as "good" reported that severe steatosis lacked predictive value for cardiovascular outcomes in NAFLD patients. 
Supplementary Table II. Continued NHLBI Quality Assessment Tool for Observational Cohort and Cross-Sectional Studies

\begin{tabular}{|c|c|c|c|c|c|c|}
\hline 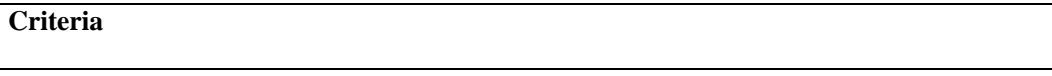 & $\begin{array}{l}\text { You SC et } \\
\text { al. [17] }\end{array}$ & $\begin{array}{l}\text { Markus MR } \\
\text { et al. [19] }\end{array}$ & $\begin{array}{l}\text { Käräjämäki } \\
\text { AJ et al. [21] }\end{array}$ & $\begin{array}{l}\text { Dunn MA et } \\
\text { al. [28] }\end{array}$ & $\begin{array}{l}\text { Targher G et } \\
\text { al. [25] }\end{array}$ & $\begin{array}{l}\text { Targher G } \\
\text { et al. [26] }\end{array}$ \\
\hline 1. Was the research question or objective in this paper clearly stated? & Yes & Yes & Yes & Yes & Yes & Yes \\
\hline 2. Was the study population clearly specified and defined? & Yes & Yes & Yes & Yes & Yes & Yes \\
\hline 3. Was the participation rate of eligible persons at least $50 \%$ ? & Yes & Yes & Yes & Yes & No & Yes \\
\hline $\begin{array}{l}\text { 4. Were all the subjects selected or recruited from the same or similar populations (including } \\
\text { the same time period)? Were inclusion and exclusion criteria for being in the study } \\
\text { prespecified and applied uniformly to all participants? }\end{array}$ & Yes & Yes & Yes & Yes & Yes & Yes \\
\hline $\begin{array}{l}\text { 5. Was a sample size justification, power description, or variance and effect estimates } \\
\text { provided? }\end{array}$ & No & Yes & Yes & Yes & Yes & Yes \\
\hline $\begin{array}{l}\text { 6. For the analyses in this paper, were the exposure( }(s) \text { of interest measured prior to the } \\
\text { outcome }(s) \text { being measured? }\end{array}$ & Yes & No & No & No & Yes & No \\
\hline $\begin{array}{l}\text { 7. Was the time frame sufficient so that one could reasonably expect to see an association } \\
\text { between exposure and outcome if it existed? }\end{array}$ & Yes & No & Yes & No & Yes & No \\
\hline $\begin{array}{l}\text { 8. For exposures that can vary in amount or level, did the study examine different levels of } \\
\text { the exposure as related to the outcome (e.g., categories of exposure, or exposure measured } \\
\text { as continuous variable)? }\end{array}$ & Yes & Yes & Yes & Yes & No & No \\
\hline $\begin{array}{l}\text { 9. Were the exposure measures (independent variables) clearly defined, valid, reliable, and } \\
\text { implemented consistently across all study participants? }\end{array}$ & Yes & Yes & Yes & Yes & Yes & Yes \\
\hline 10. Was the exposure(s) assessed more than once over time? & $\mathrm{CD}$ & No & No & No & No & No \\
\hline $\begin{array}{l}\text { 11. Were the outcome measures (dependent variables) clearly defined, valid, reliable, and } \\
\text { implemented consistently across all study participants? }\end{array}$ & No & Yes & Yes & Yes & Yes & Yes \\
\hline 12. Were the outcome assessors blinded to the exposure status of participants? & NR & Yes & Yes & NR & Yes & Yes \\
\hline 13. Was loss to follow-up after baseline $20 \%$ or less? & NR & NA & NR & NA & NR & NA \\
\hline $\begin{array}{l}\text { 14. Were key potential confounding variables measured and adjusted statistically for their } \\
\text { impact on the relationship between exposure }(s) \text { and outcome(s)? }\end{array}$ & Yes & Yes & Yes & Yes & Yes & Yes \\
\hline Rating & Good & Good & Good & Good & Good & Good \\
\hline
\end{tabular}

Available at: https://www.nhlbi.nih.gov/health-topics/study-quality-assessment-tools. CD, cannot determine; NA, not applicable; NR, not reported. 
Supplementary Table III. Continued NHLBI Quality Assessment Tool for Observational Cohort and Cross-Sectional Studies

\begin{tabular}{|c|c|c|c|c|c|c|c|}
\hline 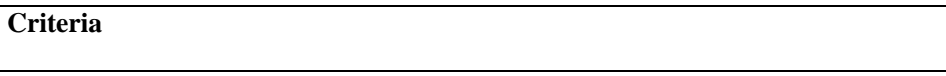 & $\begin{array}{l}\text { Hung CS et } \\
\text { al. [22] }\end{array}$ & $\begin{array}{l}\text { Targher G } \\
\text { et al. [24] }\end{array}$ & $\begin{array}{l}\text { Mantovani A } \\
\text { et al. [13] }\end{array}$ & $\begin{array}{l}\text { Ozveren O } \\
\text { et al. }[18]\end{array}$ & İşcen S [27] & $\begin{array}{l}\text { Vendhan R } \\
\text { et al. [23] }\end{array}$ & $\begin{array}{l}\text { Lee S et } \\
\text { al. [29] }\end{array}$ \\
\hline 1. Was the research question or objective in this paper clearly stated? & Yes & Yes & Yes & Yes & Yes & Yes & Yes \\
\hline 2. Was the study population clearly specified and defined? & Yes & Yes & Yes & No & Yes & Yes & Yes \\
\hline 3. Was the participation rate of eligible persons at least $50 \%$ ? & Yes & No & Yes & $\mathrm{CD}$ & Yes & No & No \\
\hline $\begin{array}{l}\text { 4. Were all the subjects selected or recruited from the same or similar populations } \\
\text { (including the same time period)? Were inclusion and exclusion criteria for being } \\
\text { in the study prespecified and applied uniformly to all participants? }\end{array}$ & Yes & Yes & Yes & $\mathrm{CD}$ & Yes & Yes & Yes \\
\hline $\begin{array}{l}\text { 5. Was a sample size justification, power description, or variance and effect } \\
\text { estimates provided? }\end{array}$ & Yes & Yes & Yes & No & Yes & Yes & No \\
\hline $\begin{array}{l}\text { 6. For the analyses in this paper, were the exposure( }(s) \text { of interest measured prior to } \\
\text { the outcome }(s) \text { being measured? }\end{array}$ & No & No & No & No & No & No & No \\
\hline $\begin{array}{l}\text { 7. Was the time frame sufficient so that one could reasonably expect to see an } \\
\text { association between exposure and outcome if it existed? }\end{array}$ & No & No & No & No & No & No & No \\
\hline $\begin{array}{l}\text { 8. For exposures that can vary in amount or level, did the study examine different } \\
\text { levels of the exposure as related to the outcome (e.g., categories of exposure, or } \\
\text { exposure measured as continuous variable)? }\end{array}$ & Yes & Yes & Yes & Yes & NA & Yes & Yes \\
\hline $\begin{array}{l}\text { 9. Were the exposure measures (independent variables) clearly defined, valid, } \\
\text { reliable, and implemented consistently across all study participants? }\end{array}$ & Yes & Yes & Yes & Yes & Yes & Yes & Yes \\
\hline 10. Was the exposure(s) assessed more than once over time? & No & No & No & No & No & No & No \\
\hline $\begin{array}{l}\text { 11. Were the outcome measures (dependent variables) clearly defined, valid, } \\
\text { reliable, and implemented consistently across all study participants? }\end{array}$ & Yes & Yes & Yes & Yes & Yes & Yes & Yes \\
\hline 12. Were the outcome assessors blinded to the exposure status of participants? & NR & Yes & Yes & Yes & Yes & Yes & Yes \\
\hline 13. Was loss to follow-up after baseline $20 \%$ or less? & NA & NA & NA & NA & NA & NA & NA \\
\hline $\begin{array}{l}\text { 14. Were key potential confounding variables measured and adjusted statistically } \\
\text { for their impact on the relationship between exposure }(s) \text { and outcome }(s) \text { ? }\end{array}$ & Yes & Yes & Yes & No & No & Yes & Yes \\
\hline Rating & Good & Good & Good & Poor* & Fair & Good & Fair \\
\hline
\end{tabular}

Available at: https://www.nhlbi.nih.gov/health-topics/study-quality-assessment-tools. CD, cannot determine; NA, not applicable; NR, not reported.

* Additional Comments (If POOR, please state why): The study lacked description regarding the study population explaining whether this is a hospital-based or community-based study, whether the cases and controls were from the same or a similar population or not. Furthermore, no justification for the sample size was performed and no statistical adjustment was performed for key potential confounding variables. However, they only excluded patients with clinical diagnosis of hypertension and diabetes mellitus.

The two studies evaluating QTc interval in NAFLD, both being rated as "good" supported that prolonged QTc interval is independently associated with the severity of NAFLD [22, 24]. Moreover, out of the fours studies that evaluated cardiac conduction abnormalities in NAFLD and supported this association, two were rated as "good" [13, 14], one was rated as "fair" [27], and one as "poor" [18]. Furthermore, IHD findings evaluated by ECG in NAFLD patients was evaluated in two studies. One study was rated as "good" and supported this association independently [23], while the other was rated as "fair" and concluded that NAFLD isn't an independent factor associated with IHD findings on ECG [29]. 
Supplementary Table IV. NHLBI Quality Assessment of Case-Control Studies

\begin{tabular}{|l|l|}
\hline Criteria & Mangi MA et al. \\
[14]
\end{tabular}

Available at: https://www.nhlbi.nih.gov/health-topics/study-quality-assessment-tools. CD, cannot determine; NA, not applicable; NR, not reported. 